\title{
Haliea salexigens gen. nov., sp. nov., a member of the Gammaproteobacteria from the Mediterranean Sea
}

Correspondence

Philippe Lebaron

lebaron@obs-banyuls.fr

\author{
Laurent Urios, $^{1,2}$ Laurent Intertaglia, ${ }^{1,2}$ Françoise Lesongeur $^{3}$ \\ and Philippe Lebaron ${ }^{1,2}$ \\ ${ }^{1}$ Université Pierre et Marie Curie - Paris 6, Laboratoire ARAGO, Avenue Fontaulé, BP 44, \\ F-66650 Banyuls-sur-Mer, France \\ ${ }^{2}$ CNRS, UMR 7621, Laboratoire d'Océanographie Biologique de Banyuls, Avenue Fontaulé, BP 44, \\ F-66650 Banyuls-sur-Mer, France \\ ${ }^{3}$ Laboratoire de Microbiologie des Environnements Extrêmes, UMR 6197, IFREMER, \\ Centre de Brest, BP 70, F-29280 Plouzané, France
}

The genus Microbulbifer was proposed by Gonzalez et al. (1997) for a Gram-negative, aerobic strain that was catalaseand oxidase-positive and possessed numerous vesicles derived from the outer membrane. Four species belonging to this genus have been described: Microbulbifer hydrolyticus (Gonzalez et al., 1997), Microbulbifer salipaludis (Yoon et al., 2003a), Microbulbifer maritimus (Yoon et al., 2004) and Microbulbifer elongatus (Yoon et al., 2003b). The latter species was originally named Pseudomonas elongata (Humm, 1946; Palleroni, 1984), but was transferred to the genus Microbulbifer on the basis of 16S rRNA gene sequence similarity, cellular fatty acid composition and respiratory quinone content. Consequently, major amounts of iso-15:0 and iso- $17: 1 \omega 9 c$ as well as ubiquinone Q-8 were defined as chemical markers of this genus (Yoon et al., 2004). Microbulbifer species have been isolated from various saline and marine environments, including salt marshes, intertidal sediments and coastal waters. In this work, a strain named $3 \mathrm{X} / \mathrm{A} 02 / 235^{\mathrm{T}}$ was isolated from seawater. On the basis of its $16 \mathrm{~S}$ rRNA gene sequence, the closest relatives were species of the genus Microbulbifer, but the similarity values were only

The GenBank/EMBL/DDBJ accession number for the 16S rRNA gene sequence of strain $3 X / A 02 / 235^{\top}$ is $A Y 576769$

An electron micrograph of a negatively stained cell of strain 3X/A02/ $235^{\top}$ and a figure showing the effects of temperature, $\mathrm{pH}$ and salinity on growth of the strain are available as supplementary material with the online version of this paper.
90-91\%. Thus, the taxonomic position and characteristics of this novel strain were analysed in more detail. On the basis of the findings, a novel genus belonging to the family Alteromonadaceae, close to the genus Microbulbifer, is proposed for this strain.

Samples of the surface microlayer of seawater in the bay of Banyuls-sur-Mer $\left(42^{\circ} 29^{\prime} \mathrm{N}^{\circ} 08^{\prime} \mathrm{E}\right)$ were collected in October 2002 by submerging a metal screen (Agogué et al., 2004). Subsamples were spread on marine agar 2216 plates (Difco) and incubated at $25^{\circ} \mathrm{C}$ for 2 weeks. Colonies were picked and purified after three subcultures. An isolate that formed cream-coloured colonies was obtained and designated strain 3X/A02/235 $5^{\mathrm{T}}$ (Agogué et al., 2005).

Microscopic observations (AX70; Olympus) showed that cells from isolate $3 \mathrm{X} / \mathrm{A} 02 / 235^{\mathrm{T}}$ were motile rods, approximately $1.6 \pm 0.3 \mu \mathrm{m}$ long and $0.5 \pm 0.2 \mu \mathrm{m}$ wide. Cells were negatively stained for transmission electron microscopy (Raguénès et al., 1997) and were shown to possess single polar flagella (see Supplementary Fig. S1, available in IJSEM Online). The Ryu KOH reaction (Powers, 1995) led to immediate cell lysis that was confirmed by microscopy (AX70; Olympus). This positive reaction indicated that the strain was Gram-negative.

Strain $3 \mathrm{X} / \mathrm{A} 02 / 235^{\mathrm{T}}$ was grown in marine broth 2216 (Difco). To determine the salinity range, marine broth 2216 was prepared according to the composition provided 
by the manufacturer, with the appropriate $\mathrm{NaCl}$ concentration. For determination of the $\mathrm{pH}$ range, MES, PIPES, AMPSO or MOPS (Sigma) was added to marine broth 2216 to achieve the appropriate $\mathrm{pH}$. Cultures were incubated at $30{ }^{\circ} \mathrm{C}$ under aerobic conditions. The methods used for the determination of growth parameters were as reported by Wery et al. (2001b). Growth was observed at 10-37 ${ }^{\circ} \mathrm{C}$, the optimum temperature being between 25 and $30{ }^{\circ} \mathrm{C}$ (see Supplementary Fig. S2, available in IJSEM Online). The strain grew at $\mathrm{NaCl}$ concentrations ranging from 7 to $70 \mathrm{~g} \mathrm{l}^{-1}$, and an optimum concentration could be defined at $40 \mathrm{~g} \mathrm{l}^{-1}$ (Supplementary Fig. S2). Growth occurred at $\mathrm{pH}$ 5.0-9.0, the optimum being $\mathrm{pH}$ 8.0. Growth decreased by $61 \%$ at $\mathrm{pH} 9.0$ relative to the value obtained at $\mathrm{pH} 8.0$, whereas a relative decrease of only $19 \%$ was observed at pH 6.0 (Supplementary Fig. S2). Anaerobic growth was checked using marine agar 2216 plates in an anaerobic jar under these optimal conditions. No growth was observed after 10 days and thus the strain should be considered as strictly aerobic.

The ability of isolate $3 \mathrm{X} / \mathrm{A} 02 / 235^{\mathrm{T}}$ to use different substrates was investigated using Biolog GN2 microplates (Tang et al., 1998) according to the manufacturer's instructions. Positive reactions were observed for Tweens 40 and 80, pyruvic acid methyl ester, succinic acid methyl ester, $\beta$-hydroxybutyric acid, $\alpha$-ketovaleric acid, succinic acid, glutamic acid, glycyl L-glutamic acid and glycerol. DMannose, $\alpha$-cyclodextrin, acetate, aspartate, succinamic acid and L-proline produced weakly positive reactions. A comparison between strain $3 \mathrm{X} / \mathrm{A} 02 / 235^{\mathrm{T}}$ and its closest relatives is presented in Table 1 .

Enzyme activities were investigated using the API ZYM system (bioMérieux) according to the manufacturer's instructions. Alkaline phosphatase, leucine arylamidase, valine arylamidase, acid phosphatase and naphthol-AS-BIphosphohydrolase exhibited positive reactions (Table 1).

An analysis of the fatty acid methyl esters was performed by the Identification Service of the Deutsche Sammlung von Mikroorganismen und Zellkulturen (DSMZ, Braunschweig, Germany). The composition for isolate $3 \mathrm{X} / \mathrm{A} 02 / 235^{\mathrm{T}}$ was as follows: $16: 1 \omega 7 c(21.2 \%), 18: 1 \omega 7 c$ (17.5\%), $15: 1 \omega 6 c(5.8 \%), 17: 1 \omega 6 c(2.7 \%), 17: 1 \omega 8 c$ (23.9\%), $10: 03-\mathrm{OH}(1.8 \%), 11: 03-\mathrm{OH}(3.3 \%), 12: 03-$ $\mathrm{OH}(1.1 \%)$, iso- $11: 03-\mathrm{OH}(3.3 \%), 11: 0(1.0 \%), 12: 0$ (1.6\%), 13:0 (1.3\%), 14:0 (1.3\%), 15:0 (4.5\%), 16:0 $(2.0 \%)$ and $17: 0(9.3 \%)$ (Table 2$)$. Two major fatty acids found in all Microbulbifer strains, iso-15:0 and iso$17: 1 \omega 9 c$, were not detected in strain $3 \mathrm{X} / \mathrm{A} 02 / 235^{\mathrm{T}}$, while $17: 1 \omega 8 c$, which is the predominant fatty acid in strain $3 \mathrm{X} /$ $\mathrm{A} 02 / 235^{\mathrm{T}}$, was poorly represented, or not detected, within the four Microbulbifer species. Fatty acids 11:0, 12:0, $13: 0,15: 1 \omega 6 c$ and $12: 03-\mathrm{OH}$, which were found in strain $3 \mathrm{X} / \mathrm{A} 02 / 235^{\mathrm{T}}$, were not detected in any Microbulbifer species. In contrast, fatty acids $10: 0$, iso- $11: 0$, iso- $15: 1$ and iso-17:0, which are always present in Microbulbifer species, were not detected in strain $3 \mathrm{X} / \mathrm{A} 02 / 235^{\mathrm{T}}$.
Analyses of respiratory quinones and polar lipids were carried out by the Identification Service of the DSMZ and Brian Tindall (DSMZ). Strain $3 \mathrm{X} / \mathrm{A} 02 / 235^{\mathrm{T}}$ had a ubiquinone (Q-8) system and the polar lipids were diphosphatidylglycerol, phosphatidylglycerol and an undefined aminophospholipid.

Genomic DNA was extracted as described by Wery et al. (2001a). The $\mathrm{G}+\mathrm{C}$ content was determined by thermal denaturation using the method of Marmur \& Doty (1962) and the conditions described by Raguénès et al. (1997). The DNA $\mathrm{G}+\mathrm{C}$ content of strain $3 \mathrm{X} / \mathrm{A} 02 / 235^{\mathrm{T}}$ was $61.4 \pm 0.2 \mathrm{~mol} \%$. The $16 \mathrm{~S}$ rRNA gene was amplified and sequenced as described by Agogue et al. (2005) and the sequence was analysed as described by Urios et al. (2006). Strain $3 X / A 02 / 235^{\mathrm{T}}$ was found to be phylogenetically affiliated to the family Alteromonadaceae in the class Gammaproteobacteria (Fig. 1). The closest relative was Microbulbifer salipaludis SM-1 ${ }^{\mathrm{T}}$, with a similarity value of $91 \%$.

Strain $3 \mathrm{X} / \mathrm{A} 02 / 235^{\mathrm{T}}$ is distinguishable from its closest phylogenetic relatives on the basis of differences in several phenotypic properties, as shown in Tables 1 and 2. Thus we propose that strain $3 \mathrm{X} / \mathrm{A} 02 / 235^{\mathrm{T}}$ represents a novel species of a novel genus belonging to the Alteromonadaceae. Because of the marine origin of strain $3 \mathrm{X} / \mathrm{A} 02 / 235^{\mathrm{T}}$ and its salinity requirement, the name Haliea salexigens gen. nov., sp. nov. is proposed.

\section{Description of Haliea gen. nov.}

Haliea (Ha'lie.a. N.L. fem. n. Haliea named after Halie, a sea nymph in Greek mythology, referring to the marine source of the first strain).

Motile Gram-negative rods. The major fatty acids are $17: 1 \omega 8 c, 16: 1 \omega 7 c, 18: 1 \omega 7 c$ and $17: 0$. The ubiquinone is Q-8 and the polar lipids are diphosphatidylglycerol and phosphatidylglycerol. Phylogenetically affiliated with the class Gammaproteobacteria within the family Alteromonadaceae. The type species is Haliea salexigens.

\section{Description of Haliea salexigens sp. nov.}

Haliea salexigens (sa.le'xi.gens. L. n. sal, salis salt, seawater; L. v. exigo to demand; N.L. part. adj. salexigens seawaterdemanding).

Displays the following properties in addition to those given in the genus description. Produces cream colonies on marine agar 2216. Cells are $1.6 \pm 0.3 \mu \mathrm{m}$ long and $0.5 \pm 0.2 \mu \mathrm{m}$ wide, with single polar flagella. The $\mathrm{G}+\mathrm{C}$ content of the type strain is $61 \mathrm{~mol} \%$. Growth occurs at $10-37{ }^{\circ} \mathrm{C}$ (optimum, $25-30{ }^{\circ} \mathrm{C}$ ), at $\mathrm{pH}$ 5.0-9.0 (optimum, $\mathrm{pH} 8.0)$ and at salinities in the range $7-70 \mathrm{~g} \mathrm{NaCl}^{-1}$ (optimum, $42 \mathrm{~g} \mathrm{l}^{-1}$ ). Positive reactions with Biolog GN2 plates are obtained for Tweens 40 and 80, pyruvic acid methyl ester, succinic acid methyl ester, $\beta$-hydroxybutyric acid, $\alpha$-ketovaleric acid, succinic acid, glutamic acid, glycyl 
Table 1. Characteristics that distinguish strain $3 X / A 02 / 235^{\top}$ from type strains of Microbulbifer species

Strains: 1, M. maritimus JCM $12187^{\mathrm{T}}$; 2, M. hydrolyticus DSM $11525^{\mathrm{T}}$; 3, M. salipaludis KCCM 41586 ${ }^{\mathrm{T}}$; 4, M. elongatus DSM 6810 $; 5$, strain 3X/ A02/235 ${ }^{\mathrm{T}}$. The quinone in all of the strains was Q-8. Data for reference type strains were taken from Gonzalez et al. (1997) and Yoon et al. (2003a, b, 2004). +, Positive; -, negative; (+), weakly positive; ND, no data available.

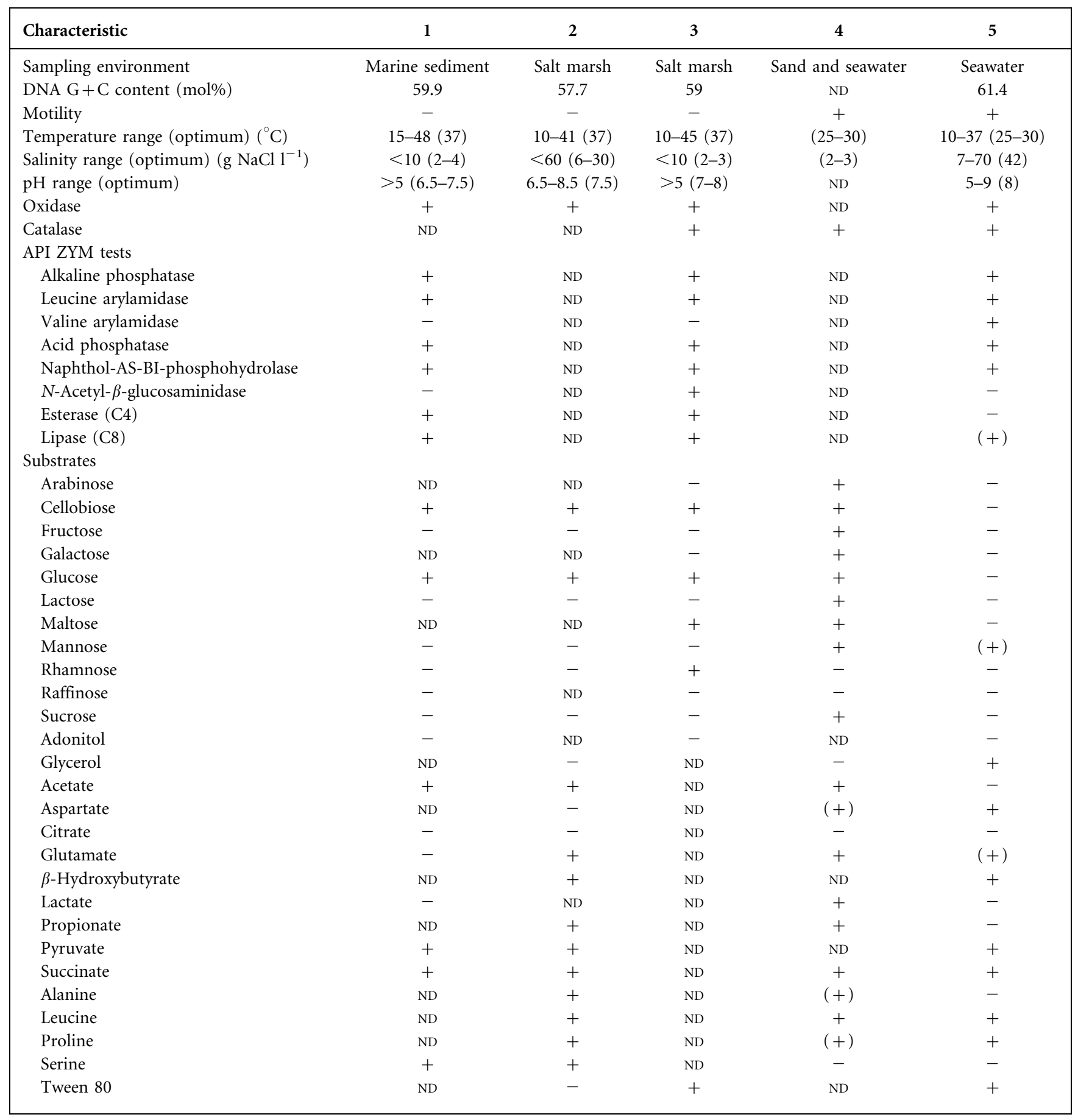

L-glutamic acid and glycerol. Positive API ZYM reactions are obtained for the following enzyme activities: alkaline phosphatase, leucine arylamidase, valine arylamidase, acid phosphatase and naphthol-AS-BI-phosphohydrolase. Oxidase- and catalase-positive. The major fatty acids also include $15: 1 \omega 6 c$ and $15: 0$. 
Table 2. Cellular fatty acid compositions (\%) of strain $3 X /$ A02/235 ${ }^{\top}$ and type strains of the genus Microbulbifer

Strains: 1, M. maritimus JCM $12187^{\mathrm{T}} ; 2$, M. hydrolyticus DSM $11525^{\mathrm{T}}$; 3, M. salipaludis KCCM $41586^{\mathrm{T}} ; 4$, M. elongatus DSM $6810^{\mathrm{T}} ; 5$, strain $3 \mathrm{X} / \mathrm{A} 02 / 235^{\mathrm{T}}$. -, Not detected. Data for reference type strains were taken from Yoon et al. (2004).

\begin{tabular}{|c|c|c|c|c|c|}
\hline Fatty acid & 1 & 2 & 3 & 4 & 5 \\
\hline $10: 0$ & 1.3 & 1.7 & 2.4 & 1.6 & - \\
\hline $11: 0$ & - & - & - & - & 1.0 \\
\hline $12: 0$ & - & - & - & - & 1.6 \\
\hline $13: 0$ & - & - & - & - & 1.3 \\
\hline $14: 0$ & 1.0 & 1.2 & 2.6 & 0.7 & 1.3 \\
\hline $15: 0$ & 1.6 & 1.5 & 1.7 & 0.9 & 4.5 \\
\hline $16: 0$ & 8.7 & 11.4 & 16.3 & 7.1 & 2.0 \\
\hline $17: 0$ & 1.3 & 2.9 & 2.2 & 2.5 & 9.3 \\
\hline $18: 0$ & - & 1.6 & 1.4 & 1.2 & - \\
\hline 17:0 cyclo & 2.3 & 5.7 & - & - & - \\
\hline $19: 0 \omega 8 c$ & 1.4 & 1.0 & - & - & - \\
\hline iso- $11: 0$ & 10.0 & 5.7 & 4.8 & 6.5 & - \\
\hline iso- $15: 0$ & 25.9 & 24.4 & 19.4 & 20.7 & - \\
\hline iso- $15: 1$ & 0.8 & 1.0 & 0.7 & 1.0 & - \\
\hline iso- $16: 0$ & - & - & - & 0.5 & - \\
\hline iso- $17: 0$ & 6.9 & 10.4 & 5.5 & 9.9 & - \\
\hline anteiso-17:0 & - & - & - & 0.8 & - \\
\hline iso- $17: 1 \omega 9 c$ & 12.6 & 10.1 & 9.5 & 11.3 & - \\
\hline $15: 1 \omega 6 c$ & - & - & - & - & 5.8 \\
\hline $17: 1 \omega 6 c$ & - & - & - & - & 2.7 \\
\hline $17: 1 \omega 8 c$ & - & 0.5 & 1.0 & 1.8 & 23.9 \\
\hline $18: 1 \omega 5 c$ & - & - & 0.7 & - & - \\
\hline $18: 1 \omega 7 c$ & 5.6 & 8.9 & 11.8 & 16.3 & 17.5 \\
\hline $10: 03-\mathrm{OH}$ & 1.7 & 1.0 & 1.2 & 1.6 & 1.8 \\
\hline $11: 03-\mathrm{OH}$ & - & - & - & - & 3.3 \\
\hline $12: 03-\mathrm{OH}$ & - & - & - & - & 1.1 \\
\hline $16: 02-\mathrm{OH}$ & - & - & 0.9 & - & - \\
\hline iso-11:0 $3-\mathrm{OH}$ & 14.2 & 6.2 & 5.7 & 7.7 & 3.3 \\
\hline iso-17:0 $3-\mathrm{OH}$ & - & - & 0.9 & - & - \\
\hline $\begin{array}{l}16: 1 \omega 7 c / \text { iso- } 15: 0 \\
2-\mathrm{OH}\end{array}$ & 2.2 & 2.7 & 7.1 & 6.0 & 21.2 \\
\hline
\end{tabular}

The type strain, $3 \mathrm{X} / \mathrm{A} 02 / 235^{\mathrm{T}}\left(=\mathrm{DSM} \quad 19537^{\mathrm{T}}=\mathrm{CIP}\right.$ $109602^{\mathrm{T}}=$ MOLA $286^{\mathrm{T}}$ ), was isolated from the surface microlayer of seawater from the bay of Banyuls-sur-Mer.

\section{Acknowledgements}

This work was supported by the Equipe Mixte de Recherche linking the Universite Pierre et Marie Curie and the Centre National de la Recherche Scientifique to the Pierre Fabre Laboratories. The project was also carried out within the framework of the MarBEF Network of Excellence ('Marine Biodiversity and Ecosystem Functioning'), which is funded in the European Community's Sixth Framework Programme (contract no. GOCE-CT-2003-505446). This publication is contribution number MPS-07061 of MarBEF. It was also partly funded by the French program 'Bio-diversité et Changement Global - project: development of a coastal microbial observatory' from the 'Institut Français de la Biodiversité' (IFB-GICC, Paris, France).

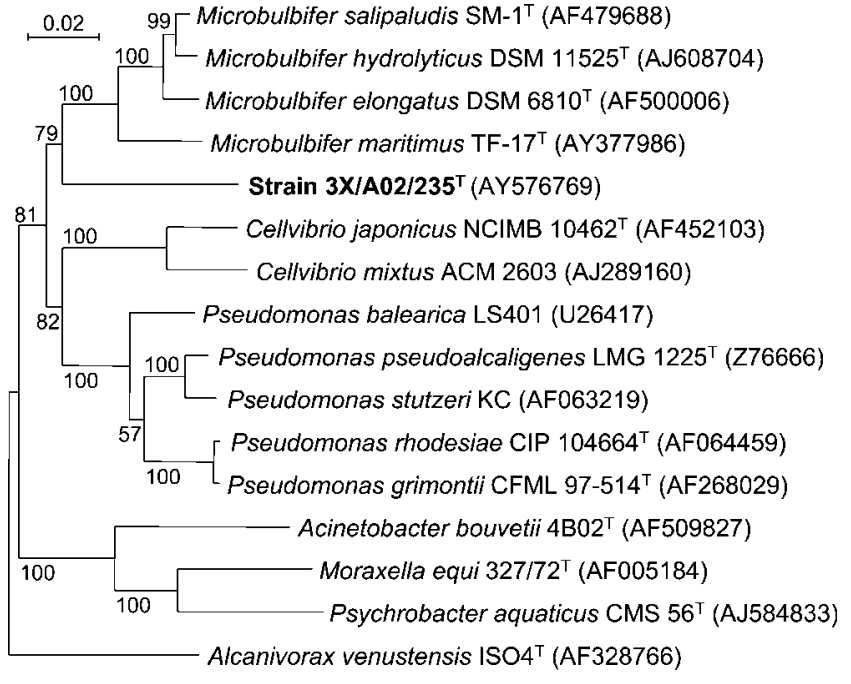

Fig. 1. Unrooted neighbour-joining phylogenetic tree (Kimura corrections), based on 16S rRNA gene sequences, showing the position of strain $3 X / A 02 / 235^{\top}$. Bootstrap percentages (based on 100 replications) are shown at branch points. Bar, 2 substitutions per 100 nucleotide positions.

\section{References}

Agogué, H., Casamayor, E. O., Joux, F., Obernosterer, I., Dupuy, C., Lantoine, F., Catala, P., Weinbauer, M. G., Reinthaler, T. \& other authors (2004). Comparison of samplers for the biological characterization of the sea surface microlayer. Limnol Oceanogr Methods 2, 213-225.

Agogué, H., Casamayor, E. O., Bourrain, M., Obernosterer, I., Joux, F., Herndl, G. J. \& Lebaron, P. (2005). A survey on bacteria inhabiting the sea surface microlayer of coastal ecosystems. FEMS Microbiol Ecol 54, 269-280.

Gonzalez, J. M., Mayer, F., Moran, M. A., Hodson, R. E. \& Whitman, W. B. (1997). Microbulbifer hydrolyticus gen. nov., sp. nov., and Marinobacterium georgiense gen. nov., sp. nov., two marine bacteria from a lignin-rich pulp mill waste enrichment community. Int J Syst Bacteriol 47, 369-376.

Humm, H. J. (1946). Marine agar-digesting bacteria of the South Atlantic coast. Bull Duke Univ Mar Stn 3, 45-75.

Marmur, J. \& Doty, P. (1962). Determination of the base composition of deoxyribonucleic acid from its thermal denaturation temperature. J Mol Biol 5, 109-118.

Palleroni, N. J. (1984). Genus Pseudomonas Migula 1894. In Bergey's Manual of Systematic Bacteriology, vol. 1, pp. 141-199. Edited by N. R. Krieg \& J. G. Holt. Baltimore: Williams \& Wilkins.

Powers, E. M. (1995). Efficacy of the Ryu nonstaining KOH technique for rapidly determining Gram reactions of food-borne and waterborne bacteria and yeasts. Appl Environ Microbiol 61, 3756-3758.

Raguénès, G., Christen, R., Guezennec, J., Pignet, P. \& Barbier, G. (1997). Vibrio diabolicus sp. nov., a new polysaccharide-secreting organism isolated from a deep-sea hydrothermal vent polychaete annelid, Alvinella pompejana. Int J Syst Bacteriol 47, 989-995.

Tang, Y. W., Ellis, N. M., Hopkins, M. K., Smith, D. H., Dodge, D. E. \& Persing, D. H. (1998). Comparison of phenotypic and genotypic techniques for identification of unusual aerobic pathogenic gramnegative bacilli. J Clin Microbiol 36, 3674-3679. 
Urios, L., Agogué, H., Lesongeur, F., Stackebrandt, E. \& Lebaron, P. (2006). Balneola vulgaris gen. nov., sp. nov., a member of the phylum Bacteroidetes from the north-western Mediterranean Sea. Int J Syst Evol Microbiol 56, 1883-1887.

Wery, N., Lesongeur, F., Pignet, P., Derennes, V., Cambon-Bonavita, M.-A., Godfroy, A. \& Barbier, G. (2001a). Marinitoga camini gen. nov., sp. nov., a rod-shaped bacterium belonging to the order Thermotogales, isolated from a deep-sea hydrothermal vent. Int $J$ Syst Evol Microbiol 51, 495-504.

Wery, N., Moricet, J.-M., Cueff, V., Jean, J., Pignet, P., Lesongeur, F., Cambon-Bonavita, M.-A. \& Barbier, G. (2001b). Caloranaerobacter azorensis gen. nov., sp. nov., an anaerobic thermophilic bacterium isolated from a deep-sea hydrothermal vent. Int J Syst Evol Microbiol 51, 1789-1796.

Yoon, J.-H., Kim, I.-G., Shin, D.-Y., Kang, K. H. \& Park, Y.-H. (2003a). Microbulbifer salipaludis sp. nov., a moderate halophile isolated from a Korean salt marsh. Int J Syst Evol Microbiol 53, 53-57.

Yoon, J. H., Kim, I. G., Kang, K. H., Oh, T. K. \& Park, Y. H. (2003b). Transfer of Pseudomonas elongata Humm 1946 to the genus Microbulbifer as Microbulbifer elongatus comb. nov. Int J Syst Evol Microbiol 53, 1357-1361.

Yoon, J. H., Kim, I. G., Oh, T. K. \& Park, Y. H. (2004). Microbulbifer maritimus sp. nov., isolated from an intertidal sediment from the Yellow Sea, Korea. Int J Syst Evol Microbiol 54, 1111-1116. 